\title{
PENGGUNAAN OBAT TRADISIONAL UNTUK PENANGANAN PENYAKIT DIABETES DI KECAMATAN KENJERAN SURABAYA
}

\author{
Wiwied Ekasari, Bambang Prajogo, Zamrotul Izza, Herra Studiawan, Suciati, Kholis Amalia, Suzana, \\ Mufarikhah, dan Tutiek Purwanti \\ Fakultas Farmasi Universitas Airlangga, Surabaya \\ E-mail: wiwied-e@ff.unair.ac.id/wiwiedeka@hotmail.com
}

\begin{abstract}
ABSTRAK. Wilayah Kenjeran yang menjadi lokasi pengabdian masyarakat ini merupakan wilayah binaan Universitas Airlangga sampai saat ini. Berdasar data pengabdian masyarakat di tahun sebelumnya, ditemukan banyak penyakit degeneratif utamanya penyakit diabetes yang menjangkit pada penduduk wilayah Kenjeran dengan penanganan yang belum maksimal karena kurangnya pengetahuan bagaimana mencegah dan mengobati baik menggunakan obat tradisional maupun obat modern. Untuk itu dilakukan pengabdian masyarakat dengan menggunakan metode penyuluhan/ edukasi tentang cara memanfaatkan tanaman obat yang telah terbukti secara ilmiah mempunyai aktivitas dapat menurunkan kadar gula dalam darah. Juga diberikan informasi mengenai penyakit diabetes, cara menyiapkan dan mengolah obat tradisional sehingga siap dikonsumsi oleh diri sendiri maupun keluarganya dalam mencegah dan mengobati penyakit Diabetes mellitus. Berdasarkan hasil kegiatan pengabdian masyarakat yang telah dilakukan dapat disimpulkan bahwa pengetahuan para peserta kader PKK kecamatan Kejeran Surabaya tentang obat tradisonal untuk penyakit diabetes menunjukkan adanya peningkatan yang bermakna setelah diberikan penyuluhan .
\end{abstract}

Kata kunci: Obat tradisional; diabetes; wilayah kenjeran Surabaya; edukasi

ABSTRACT. The Kenjeran region which is the location of community service is one of the assisted areas of Airlangga University. Based on community service data in the previous year, there were found many degenerative diseases, especially diabetes with a less than optimal treatment due to lack of knowledge on how to prevent and treat both traditional medicine and modern medicine. For this reason, community service is carried out by using counseling / education methods on how to utilize medicinal plants that have been scientifically proven to have activities that can reduce blood sugar levels. The participant also will be given information about diabetes, how to prepare and process traditional medicines so that they are ready to be consumed by themselves and their families in preventing and treating diabetes mellitus. Based on the results of community service activities that have been carried out, it can be concluded that the knowledge of the participants in Kejeran sub-district Surabaya regarding traditional medicines for diabetes showed a significant increase after being given counseling

Key words: Traditional medicine; diabetes; Surabaya's popularity area; education

\section{PENDAHULUAN}

Adanya penyakit degeneratif perlu mendapatkan perhatian serius dari pemerintah dan praktisi kesehatan karena pada perkembangannya menimbulkan permasalahan yang disebabkan oleh keterbatasan kemampuan ekonomi dan pengetahuan cara hidup sehat. Keterbatasan tersebut menyebabkan orang tanpa sadar melakukan tindakan yang menurunkan kualitas hidup, seperti tidak berobat kepada dokter atau tidak patuh kepada nasehat dokter, dan tidak menganut pola hidup sehat. Mereka juga mengkonsumsi berbagai tanaman dan ramuan obat tradisional tanpa memahami kegunaan dan cara pemakaian secara benar.

Salah satu penyakit degeneratif yang menyerang masyarakat di kota Surabaya khususnya di wilayah kecamatan Kenjeran Surabaya adalah diabetes mellitus. Diabetes mellitus atau sering juga dikenal oleh masyarakat dengan istilah kencing manis adalah suatu penyakit gangguan metabolik menahun yang ditandai dengan peningkatan konsentrasi glukosa di dalam darah (hiperglikemi). Hal ini dihubungkan dengan keadaan abnormalitas metabolisme karbohidrat, lemak dan protein yang terjadi karena kelainan sekresi insulin, kerja insulin (sensitivitas) atau keduanya, dari faktor genetik serta faktor lingkungan dan mengakibatkan komplikasi kronis. Insulin sendiri adalah hormon yang mengatur keseimbangan kadar gula darah.

Berdasarkan data Riset Kesehatan Dasar (Riskesdas) di Indonesia terdapat 10 juta orang penderita diabetes, dan 17,9 juta orang beresiko menderita penyakit ini. Sementara Provinsi Jawa Timur termasuk dalam 10 besar prevalensi penderita diabetes Indonesia atau menempati urutan ke-Sembilan dengan prevalensi 6,8 (Kominfo Jatim, 2015). Jumlah tersebut meningkat dari tahun ke tahun dan Surabaya menjadi wilayah dengan jumlah penderita Diabetes Mellitus tertinggi se-provinsi Jawa Timur dengan penderita mencapai 14.377 pertahun. Penderita tidak lagi didominasi oleh penduduk usia 50 tahun ke atas namun mulai mengincar penduduk di bawah usia 15 tahun dengan prevalensi prediabetes pada usia produktif pun terus meningkat (Kementrian Kesehatan RI, 2014)

Peningkatan jumlah penderita kencing manis diketahui melalui interaksi yang dilakukan pada kegiatan pengabdian masyarakat sebelumnya Fakultas Farmasi Universitas Airlangga di kota Surabaya. Sebagian dari warga mengaku sedang menjalani pengobatan DM, sebagian lain memilih menggunakan tanaman obat dan ramuan obat tradisional Indonesia (Faturrohmah, 2015).

Potensi peningkatan prevelansi DM perlu diantisipasi dengan melakukan tindakan preventif, suportif 
dan promotif. DM merupakan penyakit degeneratif yang tidak bisa disembuhkan tapi bisa dicegah sehingga tidak mengarah pada komplikasi lebih lanjut dan menjadikan penderita mempunyai mutu hidup yang lebih baik.

Berdasarkan hal tersebut di atas, maka diperlukan keberlanjutan penyelenggaraan program pengabdian masyarakat oleh Fakultas Farmasi Universitas Airlangga. Apoteker sebagai bagian dari tenaga profesional di bidang kesehatan memiliki peran penting terutama pemberian informasi dan edukasi terkait upaya pencegahan DM, peningkatan capaian target terapi pada penggunaan insulin dan oral antidiabetes, pemanfaatan tanaman obat dan penyiapannya untuk pemakaian diri sendiri serta pengaturan gaya hidup sehat di antaranya pola makan dan olah raga. Untuk diketahui Diabetes Melitus sebagai penyakit degeneratif yang prevalensinya semakin meningkat sejak tahun 2010 dapat dimaksimalkan peng-obatannya bila keahlian masyarakat dalam menggunakan dan menyimpan obat sudah baik (Budiman, 2017).

Beragam upaya yang telah dilakukan selama ini umumnya ditujukan langsung hanya untuk penderita DM. Namun sebenarnya pemberian informasi tidak cukup hanya diberikan kepada penderita DM saja bila diinginkan adanya perubahan perilaku sehat, melainkan juga harus diberikan pada keluarga dan lingkungan sekitar (Mayberry and Osborn, 2012). Penyediaan informasi terkait DM yang diberikan kepada penderita dan keluarga telah dilaporkan memiliki hubungan dengan peningkatan kepatuhan terapi (Lambert et al., 2001). Penelitian lain menunjukkan bahwa penderita yang memiliki tingkat pengetahuan dan pemahaman yang tinggi mengenai obat-obat antidiabetes berkorelasi positif terhadap pengendalian glukosa darah dan peningkatan kepatuhan terapi (Mc.Pherson et al., 2008).

Untuk mencapai keberhasilan, maka program tersebut diselenggarakan dalam bentuk penyuluhan yang dilaksanakan oleh staf pengajar pada Departemen Farmakognosi dan Fitokimia yang menguasai bidangnya. Seperti diketahui wanita mempunyai peranan penting dalam memelihara dan menjaga kesehatan keluarganya (Kuswinarti, 2014), oleh karena itu pada penyuluhan kali ini akan diberikan utamanya pada ibu-ibu kaderkader PKK demgan harapan dapat meneruskan informasi tersebut pada keluarga dan masyarakat sekitar. Melalui penyuluhan tersebut, maka diharapkan masyarakat mendapatkan pemahaman dan penggunaan tanaman obat yang benar untuk menanggulangi penyakit DM sekaligus menjadi komplementer pengobatan selain penggunaan obat modern. Selanjutnya peningkatan wawasan tersebut akan dapat bermanfaat sebagai upaya pencegahan dan penanggulangan penyakit kencing manis.

\section{METODE}

Berdasarkan permasalahan yang dihadapi, maka kegiatan pengabdian ini dirancang untuk memberikan edukasi oleh Apoteker untuk pemberdayaan para kader PKK kawasan kecamatan Kenjeran Surabaya guna mencegah pertambahan insidensi DM, meningkatkan kepatuhan penderita DM terhadap terapi yang dijalani serta perubahan gaya hidup dengan menjaga pola makan yang sehat.

Untuk tahap persiapan maka dilakukan pemilihan tanaman obat yang telah terbukti secara ilmiah dapat menurunkan kadar gula darah, pembuatan Modul Obat Tradisional serta pembuatan buku saku tanaman obat untuk penyakit diabetes.

Tahap pelaksanaan, dilakukan pemberian pre test pada para peserta mengenai pengetahuan dan wawasan yang telah dimiliki seputar penyakit DM dan terapinya sebelum pemberian materi oleh pembicara. Selanjutnya pemberian materi melalui metode ceramah oleh pakar obat tradisional dari Fakutas Farmasi Unair. Adapun materi yang diberikan yaitu: (1) Informasi mengenai penyakit DM, pencegahan dengan menerapkan gaya hidup sehat. (2) Pengenalan dan pemanfaatan tanaman obat yang telah terbukti secara ilmiah mempunyai aktivitas menurunkan kadar gula darah, (3) Demo bagaimana mengolah dan menyiapkan obat tradisional untuk bisa diaplikasikan pada diri sendiri maupun keluarga. Tahap pelaksanaan dilanjutkan dengan tanya jawab dan diskusi dengan peserta serta diakhiri dengan post test dengan pertanyaan yang sama dengan pre test. Setelah kegiatan terlaksana, kemudian dilakukan evaluasi dan pembuatan laporan kegiatan.

\section{HASIL DAN PEMBAHASAN}

Sebelum dilakukan penyuluhan, peserta sebanyak 50 orang yang merupakan kader-kader PKK dari 4 kelurahan di kecamatan Kenjeran yaitu kelurahan Bulak Banteng, Tambak Wedi, Kedinding dan Sidotopo diberikan kuesioner dan pre test terlebih dahulu. Materi penyuluhan yang diberikan meliputi pengetahuan mengenai penyakit diabetes itu sendiri dan penanganannya menggunakan tanaman obat tradisional, dilanjutkan pengenalan dan pemanfaatan tanaman obat yang telah terbukti secara ilmiah mempunyai aktivitas menurunkan kadar gula darah. Tanaman yang dikenalkan diantaranya adalah herba sambiloto (Agarwal et al, 2005), buah pare (Ahmad et al, 1999), buah mengkudu (Kumar, 2007), biji juwet (Sidana et al, 2017), bawang merah (Eldin et al, 2010). dan bawang putih ( Asrhaf, 2011) Setelah pemberian materi peserta kemudian diberikan post test.

Berikut ini adalah data para peserta dan hasil dari pre dan post test kegiatan penyuluhan di kecamatan Kenjeran.

Data demografi peserta menunjukkan kegiatan ini diikuti oleh peserta dengan usia terbanyak antara 41-50 tahun (46\%).

Tabel 1. Data usia dari para peserta penyuluhan

\begin{tabular}{ccc}
\hline Usia & Jumlah & \% \\
\hline $21-30$ tahun & 0 & 0 \\
31-40 tahun & 5 & 10 \\
$41-50$ tahun & 23 & 46 \\
$51-60$ tahun & 16 & 32 \\
$>61$ tahun & 5 & 10 \\
Tidak Ada Keterangan & 1 & 2 \\
\hline Total & $\mathbf{5 0}$ & $\mathbf{1 0 0}$ \\
\hline
\end{tabular}




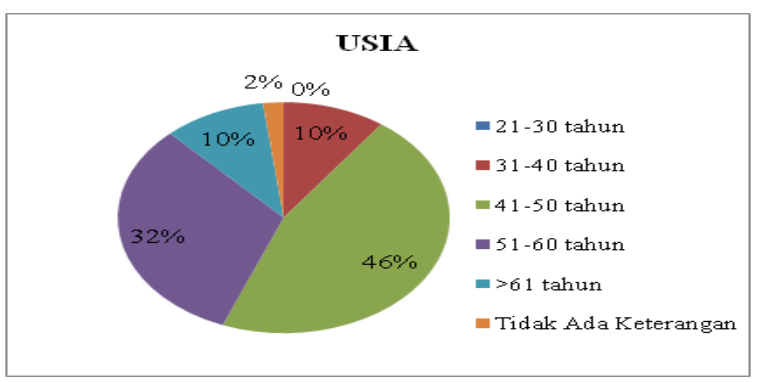

Gambar 1. Pie chart "Usia" dari para peserta

Data ini sangat menguntungkan karena dengan usia matang yang masih produktif, diharapkan kader PKK ini dapat secara maksimal menyampaikan ilmu yang telah didapat pada warga sekitar utamanya di wilayah Kecamatan Kenjeran.

Selain itu dari segi pendidikan, lebih dari separuh peserta penyuluhan adalah warga yang mempunyai pendidikan setara SMA, bahkan sebanyak $20 \%$ merupakan lulusan dari perguruan tinggi.

Tabel 2. Data pendidikan terakhir dari para peserta penyuluhan

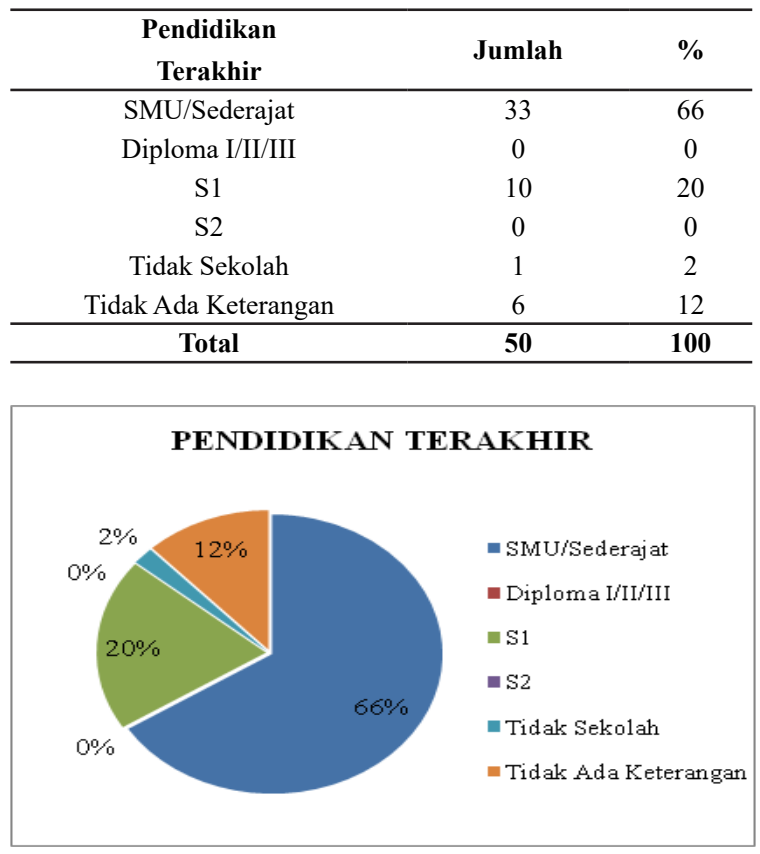

Gambar 2. Pie chart "Pendidikan Terakhir" dari para peserta
Berdasar data jenjang pendidikan peserta tersebut besar harapan mereka akan mudah menerima materi yang diberikan sehingga tujuan pengabdian lebih mudah tercapai. Hal ini dimungkinkan karena pendidikan dapat mempengaruhi seseorang termasuk juga perilaku seseorang akan pola hidup. Pada umumnya makin tinggi pendidikan seseorang makin mudah untuk dapat menerima informasi (Nursalim, 2003).

Sedangkan dari data pekerjaan, hampir semua peserta adalah seorang ibu rumah tangga. Hal ini juga merupakan faktor yang menguntungkan karena diharapkan mereka mempunyai waktu yang mencukupi untuk dapat mengaplikasikan pengetahuan yang diperoleh pada keluarga sendiri, kepada masyarakat sekitar bahkan dapat juga menjadi sumber penghasilan tambahan bila mereka akan menjual produk-produk simplisia tanaman obat yang berkhasiat sebagai antidiabetes seperti yang telah disuluhkan.

Tabel 3. Data pekerjaan dari para peserta penyuluhan

\begin{tabular}{ccc}
\hline Pekerjaan & Jumlah & $\mathbf{\%}$ \\
\hline PNS & 1 & 2 \\
Wiraswasta & 4 & 8 \\
IRT & 42 & 84 \\
Petani/Pedagang & 1 & 2 \\
Pensiunan & 0 & 0 \\
TNI/Polri & 0 & 0 \\
Tidak Ada Keterangan & 2 & 4 \\
\hline Total & $\mathbf{5 0}$ & $\mathbf{1 0 0}$ \\
\hline Data berikut adalah hasil pre-post test dari total
\end{tabular}

50 peserta penyuluhan yang mengikuti kegiatan ini:

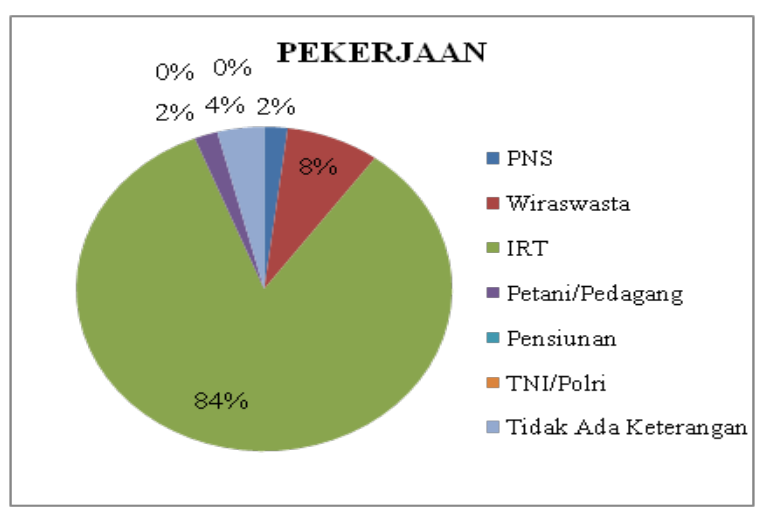

Gambar 3. Pie chart "Pekerjaan" dari para peserta

Tabel 4. Contoh soal pada Pre-Post Test penyuluhan

\begin{tabular}{|c|c|c|c|c|c|}
\hline \multirow{2}{*}{ No. } & \multirow{2}{*}{ Soal } & \multicolumn{2}{|c|}{ Pre } & \multicolumn{2}{|c|}{ Post } \\
\hline & & $\mathrm{B}$ & $\mathrm{S}$ & $\mathrm{B}$ & $\mathrm{S}$ \\
\hline 1 & Pengertian mengenai Penyakit Diabetes Melitus & 5 & 45 & 17 & 33 \\
\hline 2 & Pernyataan yang bukan tujuan pengobatan Diabetes Melitus & 11 & 39 & 18 & 32 \\
\hline 3 & Target capaian gula darah acak pada pengobatan Diabetes Melitus & 5 & 44 & 33 & 17 \\
\hline 4 & Aktivitas yang bukan anjuran untuk mencegah Diabetes Melitus & 7 & 43 & 20 & 30 \\
\hline 5 & Tanaman yang dikenal bisa membantu penyembuhan penyakit diabetes ( Sambiloto : Agarwal et al, 2005) & 45 & 5 & 49 & 1 \\
\hline 6 & $\begin{array}{l}\text { Buah dari tanaman obat yang dapat dipakai untuk membantu mengatasi diabetes ( Buah } \\
\text { Pare : Ahmad et al, 1999) }\end{array}$ & 34 & 16 & 50 & 0 \\
\hline 7 & Pemakaian Obat tradisional yang benar & 37 & 13 & 38 & 12 \\
\hline 8 & Cara cepat mengatasi hipoglikemia bila posisi di rumah & 35 & 15 & 40 & 10 \\
\hline 9 & Penyakit yang bukan merupakan komplikasi jangka panjang Diabetes Melitus & 29 & 21 & 31 & 19 \\
\hline
\end{tabular}


Berdasar data dapat dilihat pada semua soal yang diberikan kepada para peserta mengalami peningkatan jumlah yang menjawab benar setelah mengikuti penyuluhan. Nilai yang didapat oleh total 50 peserta ketika pre test dan post test dapat dilihat sebagai berikut:

Tabel. Nilai Pre-Post Test dari 50 Peserta

\begin{tabular}{lcll}
\hline \multicolumn{1}{c}{ Pre Test } & \multicolumn{2}{c}{ Post Test } \\
\hline Nilai rata-rata & 41 & Nilai rata-rata & 60 \\
Nilai tertinggi & 69 & Nilai tertinggi & 92 \\
Nilai terendah & 8 & Nilai terendah & 23 \\
\hline
\end{tabular}

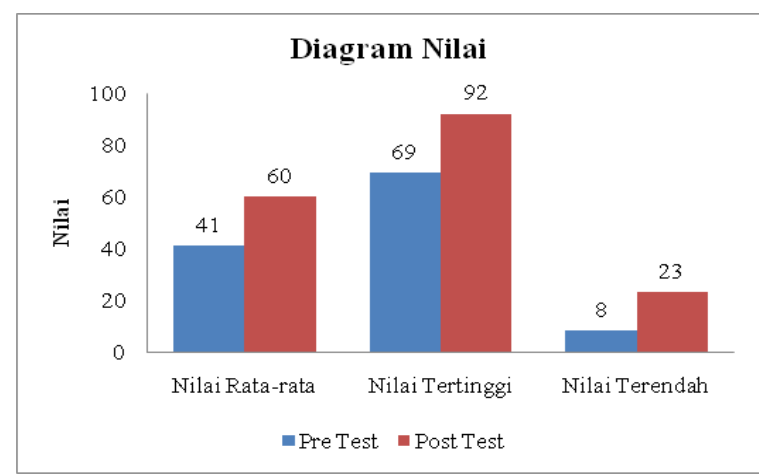

Gambar 4. Histogram nilai hasil pre test dan post test dari para peserta

Berdasar hasil pre dan post test dapat dilihat terjadinya peningkatan nilai yang cukup besar pada peserta setelah diberikan penyuluhan. Bahkan nilai tertinggi dari peserta penyuluhan ada yang mendekati nilai sempurna yaitu 92, jauh meningkat dibandingkan ketika sebelum diberikan penyuluhan yang hanya sebesar 69 . Begitu pula dengan nilai rata-rata dan nilai terendah dari yang didapat peserta, semuanya mengalami peningkatan yang cukup bermakna dibandingkan dengan hasil pre test. Namun demikian dari hasil pre dan post test masih ada yang perlu mendapatkan perhatian, terutama pengetahuan peserta mengenai penyakit diabetes itu sendiri dan aktivitas untuk mencegah penyakit diabetes. Dari hasil evaluasi dapat diketahui bahwa walaupun ada peningkatan setelah diberikan penyuluhan tetapi hampir separuh pemahaman peserta masih belum tepat. Sehingga untuk kedepannya diperlukan juga penambahan materi yang lebih mendalam tentang hal ini. Sedangkan pengetahuan tentang tanaman obat dan pemakaiannya untuk membantu mengatasi penyakit diabetes dari hasil evaluasi sudah menunjukkan hasil ysng sangat baik.

Secara umum kegiatan pengabdian masyarakat yang telah dilakukan dan dikemas dalam bentuk penyuluhan kesehatan berjalan dengan sangat baik sesuai dengan yang diharapkan. Hasil evaluasi secara umum menunjukkan adanya peningkatan pengetahuan dari peserta secara bermakna. Kegiatan seperti ini sangat diharapkan oleh masyarakat yang ditunjukkan dengan adanya permintaan khusus untuk mengadakan kegiatan serupa agar masyarakat mendapatkan banyak pengetahuan kesehatan yang dapat diaplikasikan dalam kehidupan sehari-sehari, sehingga tercapai masyarakat Indonesia yang sehat dan produktif.

\section{SIMPULAN}

Berdasarkan hasil kegiatan pengabdian masyarakat yang telah dilakukan dapat disimpulkan bahwa pengetahuan para peserta kader PKK kecamatan Kejeran Surabaya tentang obat tradisonal untuk penyakit diabetes menunjukkan adanya peningkatan yang tinggi setelah diberikan penyuluhan.

\section{UCAPAN TERIMAKASIH}

Kegiatan ini berlangsung dengan dana RKAT Tahun Anggaran 2018 Fakultas Farmasi Universitas Airlangga Surabaya.

\section{DAFTAR PUSTAKA}

Agarwal R, Sulaiman SA, and Mohamed M (2005). Open Label Clinical Trial to Study Adverse Effects and Tolerance to Dry Powder of the Aerial Part of Andrographis Paniculata in Patients Type 2 with Diabetes Mellitus. Malays J Med Sci. 2005 Jan; 12(1): 13-19.

Ahmad N, Hassan MR, Haler H, Bennor KS. (1999). Effect of Momordica charantia (Karolla) extract on fasting and postprandial serum glucose levels in NIDDM patients. Bangladesh Med Res Counc Bull, Apr ;25 (1) : 11-3

Ashraf R, Khan RA, Ashraf I. 2011. Garlic (Allium sativum) supplementation with standard antidiabetic agent provides better diabetic control in type 2 diabetes patients. Pak.J.Pharm Sci. Oct 24(4) :565-570

Budiman Arif. 2017. Peningkatan Pemahaman Penggolongan Cara Penggunaan dan Penyimpanan Obat serta Pengenalan Obat Tradisional buat Penyakit Diabetes di SMU Muhammadiyah Pangandaran. Dharmakarya.Vol 6, No.2

Eldin IMT, Ahmed EM, A. Elwahab HM. (2010). Preliminary study of the clinical hypoglycemic effect of Allium cepa (Red onion) in Type 1 and type 2 diabetic patients. Environ Health Insight:;4:71-77

Faturrohmah, A. 2015. Pengabdian kepada Masyarakat Fakultas Farmasi dalam rangka Dies Natalis Universitas Airlangga (Pemeriksaan Kesehatan dan Pengobatan Gratis I Kecamatan Kenjeran Surabaya. Lap. Pengmas Unair.

Izzah, Z. 2015. IbM. Lansia Penderita Diabetes Mellitus yang menerima polifarmasi di Kedung Tarukan dan Wonorejo Surabaya. Unpublish.

Kumar GS. 2007. The effect of Noni (Morinda citrifolia L.) in type 2 diabetes mellitus in inadequately controlled patients. Noni Cli Res J.1(12):204 
Kuswinarti, Sitorus T dan Ruslan A. (2014). Pemberdayaan wanita dengan Peningkatan tentang Obat, Pembudidayaan Tanaman Obat dan Pembuatan Berbagai sediaan Obat Herbal untuk PenyakitPenyakit umum di Masyarakat di Desa Sadari dan Haurseah Kecamatan Argapura Kabupaten Majalengka. Dharmakarya. Vol.3, No.1.

Kementrian Kesehatan RI, 2014. Pusat Data dan Informasi. http://www.depkes.go.id/resources/ download/pusdatin/infodatin/infodatin-diabetes. pdf. 25 Maret 2018.

KominfoJatim. 2015. Masih tinggi Prevalensi Daibetes di Jatim. Jatim news room : 30 september 2015

Lambert, E.J.F. Boufy, M.L and Van Hulten, R.P. 2010. The Role of community Pharmacist in fulfilling information needs of patients starting oral antidiabetics. Research in Social and Administrative Pharmacy, 6: 354-364.

Mayberry, L.S and Osborn, C.Y. 2012. Family support, medication adherence, and glycaemic control among adult with type 2 diabetes. Diabetes care, 35: 1239-1245.

McPherson, ML., Smith S.W., Powers, A and Zuckerman ,I.H. 2008. Association between diabetes patient's knowledge about medication and their blood glucose control. Research in Social and Administrative Pharmacy, 4: 37-45.

Nursalam. (2003). Pendidikan Dalam Pengetahuan. Diperoleh pada 25 Februari 2015. http:www. infokesehatan.com 